\title{
The evolution of meanings: an empirical analysis of the social media industry
}

\author{
Silvia Sanasi ${ }^{\circledR}$, Daniel Trabucchi ${ }^{\circledR}$, Elena Pellizzoni ${ }^{\circledR}$ and \\ Tommaso Buganza \\ Department of Management, Economics and Industrial Engineering, \\ Politecnico di Milano, Milan, Italy
}

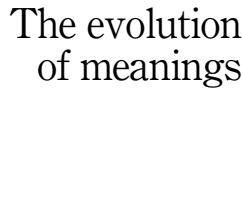

97

Received 16 September 2020 Revised 21 December 2020 Accepted 27 January 2021

\begin{abstract}
Purpose - Innovation dynamics have been the object of study of several researchers, focusing in particular on technological innovation and the emergence of a dominant design. However, these models have been challenged by how the pervasiveness of digital technologies is speeding up the pace at which innovation evolves. On the other hand, a growing body of literature in innovation management has started underlining the relevance of new product and service meanings as a source of innovation.

Design/methodology/approach - This research aims to study the different innovation dynamics within an industry, investigating not only how companies react to fast-changing functional advancements but rather how their behavior changes as shifts in meaning occur. To properly assess the phenomenon, this longitudinal study analyzes the social media industry, strongly subjected to continuous functional advancements, through a deep dive in the 160 innovations introduced between 2003 and 2017 by the eight leading players in the industry.

Findings - Our results illustrate the co-existence of different approaches to innovation within an industry and hint that consequent and fast cycles of innovation in both functionalities and meanings discourage the emergence of a dominant design.

Practical implications - Our results help managers and innovators acknowledge the possibility to leverage not just on the technological dimension of innovation but also the reason why people use a given product or service, innovating its meaning. Furthermore, our results recognize the co-existence of different innovation streams upon which innovators can act.

Originality/value - This research contributes to the extant literature in innovation management, extending the classical models of innovation dynamics by including the evolution of innovations of meaning in relation to technological innovation.
\end{abstract}

Keywords Innovation dynamics, Innovation cycles, Innovation of meaning, Technological innovation, Social media

Paper type Research paper

\section{Introduction}

The way innovation evolves in a market has been the object of study for several scholars. The seminal work proposed by Tushman and Anderson (1986) and Abernathy and Utterback (1978) has given rise to an entire literature stream that investigates the evolutionary dynamics of technological innovation and how technological discontinuities lead to a series of cycles of innovation. Through an era of ferment, industries see the establishment of a "dominant design" - i.e., a design that becomes the industry standard (Abrahamson and

(C) Silvia Sanasi, Daniel Trabucchi, Elena Pellizzoni and Tommaso Buganza. Published by Emerald Publishing Limited. This article is published under the Creative Commons Attribution (CC BY 4.0) licence. Anyone may reproduce, distribute, translate and create derivative works of this article (for both commercial and non-commercial purposes), subject to full attribution to the original publication and authors. The full terms of this licence may be seen at $\mathrm{http}$ ://creativecommons.org/licences/by/4.0/legalcode

The authors would like to thank the editors and the anonymous reviewers, who helped significantly in enhancing the study's contributions as a result of the revision process.

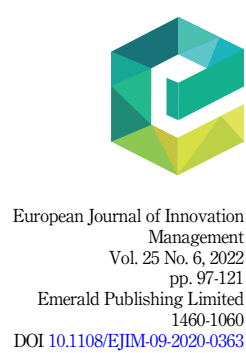


EJIM

25,6

Rosenkopf, 1997; Anderson and Tushman, 1990; Tripsas, 1997) through a process of selection and refinement (Grodal et al., 2015) - until a new technological discontinuity takes place in the market and the cycle is repeated (Tushman et al., 1997).

Recent developments in the diffusion of digital technologies are somehow challenging this mechanism. Downes and Nunes (2014), through their work on Big Bang Disruption, have described the mechanisms that help companies foster innovation by generating significant impact in the market, with a specific focus on the incredible speed of their cycles. Although previous studies argued it could take years to reach a dominant design (e.g., Tripsas, 1997), the process is now happening at a much higher speed and carries potentially disruptive outcomes for incumbents.

Other studies represent the emergence of dominant designs as closely related to the technology itself. In contrast, the so-called "convergent designs" are more common in industries characterized by a substantial symbolic value of products and services, such as the design-intensive ones (e.g., Cappetta et al., 2006; Magistretti et al., 2019, 2020). One of the critical features of these models is their focus on entire industries, representing the evolution of innovation through the effort of different companies that rework and innovate products offered by competitors (Tripsas, 1997).

Over the last decade, scholars have pointed to another dimension of innovation: the meaning (Morillo et al., 2015; Candi et al., 2016; Kumar and Noble, 2016; Goto, 2017; Verganti, 2017; Verganti et al., 2020). Traditional innovation theories consider product or service functionalities as the primary object of product innovation (e.g., Anderson and Tushman, 1990; Von Hippel, 1986). While design is commonly understood as the means to operate on product aesthetics and functional features, this view disregards the strategic relevance that design can assume as the source of "meaningful distinction" between one product and another (Lorenz, 1994). Building on this view, recent models suggest that a hedonic dimension, dealing with the meaning of a product or a service -intended as the reason why people buy it and use it - may play an essential role in the innovation process (e.g., Candi et al., 2016; Kumar and Noble, 2016; Verganti, 2009, 2017).

Companies like Yankee Candle did not change the functional attributes of the object they produce: their candles are not brighter than their competitors' but they offer buyers a new reason to purchase them. They create a pleasant environment with their scent, awarding users with an emotional experience of the product that is different from its original functional dimension: lighting (Verganti, 2017).

The meaning dimension of innovation has indeed raised the interest of several scholars in recent times (e.g., Dell'Era et al., 2017; Goto, 2017; Altuna et al., 2017; Artusi and Bellini, 2020a; Verganti et al., 2020). Existing studies investigate the role that new entrants' contributions play in introducing new meanings (e.g., Jepsen et al., 2014; Morillo et al., 2015), and the way incumbents react to it (e.g., Trabucchi et al., 2017). Some scholars have investigated meanings as manifest in product languages although only providing generalizable considerations to product-centric industries and design-intensive industries (e.g., Ravasi and Lojacono, 2005). Others have focused on the way meanings can be embodied in a service (Pinto et al., 2017; Artusi and Bellini, 2020a, b) or the team dynamics that may foster meaning-making within the innovation process (Bellis and Verganti, 2020). Existing studies focus on the process and the features of innovation, rather than its dynamics at the industry level: the way meanings evolve within a given industry is still unclear.

As the role of meaning in innovation is expanding from design-intensive industries to several other domains (e.g., technology-based, Dell'Era et al., 2017; music industry, Trabucchi et al., 2017; retail, Pinto et al., 2017; Artusi and Bellini, 2020a, b) and that technology is often considered an enabler for new meanings (Verganti, 2009; Dell'Era et al., 2017; Goto, 2017; Magistretti and Dell'Era, 2019; Magistretti et al., 2020) the aim of this research is to dig into the related innovation dynamics, by not just considering the functional improvements brought 
by innovation but also the shift in the product/service meaning - i.e., the reason why customers buy and love a given product or service (Verganti, 2009).

In other words, are the reference models that have guided research over the last decades still valuable when considering not only technologies but also meanings?

This research is based on the social media industry, proposing a longitudinal study on the eight leading players in the field (i.e., Facebook, Twitter, Linkedin, WhatsApp, Snapchat, Google +, Instagram and Pinterest). In particular, 160 innovations introduced in the field between May 2003 and June 2017 have been analyzed through the two different perspectives (i.e., respectively looking at innovation in functionality and meaning) with the aim of examining the innovation dynamics taking place within the industry.

This study contributes to traditional and established models of innovation dynamics in technological innovation by extending them to include the innovation of meaning dimension, investigating the way meanings evolve within an industry. Consequently, theoretical and managerial implications are drawn, building new theory on innovation dynamics in reaction to discontinuities generated both by functional innovation and innovation in product and service meanings while providing managers with actionable suggestions to navigate through such discontinuities.

\section{Different kinds of innovation: technology and meaning}

\section{Innovation dynamics: a technological perspective}

Tushman and Anderson (1986) define the concept of technological discontinuity by proving the existence of two main phases in the development of technology: an era of ferment and an era of incremental change. Their seminal work sets the basis for a whole stream of research dealing with the implications of innovation for market dynamics. Later works illustrate the way the phases rely on a cyclical model based on technological breakthroughs, defining four different and cyclical phases within this evolution - i.e., variation (technological discontinuity), fluid phase (era of ferment), selection (dominant design) and retention (era of incremental change) (Anderson and Tushman, 1990; Tushman et al.,1997). These phases repeat themselves in between technological discontinuities occurring in the market, causing the continuous redefinition of the industry's dominant design. Since Tushman et al.'s (1997) framework also identifies the existence of so-called innovation streams as products are complect systems, they identify subsystems within which products and their functionalities can be subdivided. The seminal work by Utterback and Suaréz (1993) supplements this perspective, investigating the emergence of dominant designs -innovations that take over existing technologies by setting a new industry standard - bringing most companies in the market to compete on the same technology.

Within this process of evolution, established firms seem to play an extremely important role in technology development, in particular when addressing customer needs (Christensen and Bower, 1996) since customer satisfaction plays an important role in the diffusion of technology to define a standard in the market (Abrahamson and Rosenkopf, 1997; Nokelainen and Dedehayir, 2015). Companies that are able to summarize the innovations proposed by competitors and set a dominant design are rewarded with relevance in the market (e.g., Anderson and Tushman, 1990; Tushman et al., 1997; Utterback, 1993; McGrath, 1998). Several studies have built on this view. For example, Tegarden et al. (1999) argue that betting on the right design to become dominant in the market is a crucial driver to industry survival. The chance to set a market standard or a dominant design can enable winner-takes-all configurations (Lee et al., 2006; Schilling, 2002). Companies thus work on the same technology in the pursuit of innovation until one proposes the "winning" architecture, becoming the dominant design. This view is relevant for two main reasons. First, it demonstrates how competing companies may build on the innovations introduced by other companies together.
The evolution of meanings (1) 
EJIM

25,6

100

Second, it illustrates how the company that wins the market is the setter of the dominant design (e.g., Tripsas, 1997; Tushman et al., 1997).

However, although more recent research has investigated the phenomenon of technological discontinuity and its alternation with periods of stall (e.g., Perez, 2010; Sood and Tellis, 2005), these models have been challenged by digital technologies and speed of disruption, regarding the overall time taken to set a dominant design and to reach the following technological discontinuity (e.g., Ghezzi, 2013; Trabucchi et al., 2019). Indeed, the impact of disruptive technologies on innovation dynamics within an industry has been widely studied in extant research (Christensen and Bower, 1996; Christensen, 1997; Hopp et al., 2018; Roy and Sarkar, 2016) concluding that, as the pace of technological advancement in an industry outruns the demand for technically improved products, new entrants are likely to introduce disruptive products that are technologically inferior to existing incumbent offerings but offer a new mix of features that are better able to serve specific niches of market and progressively gain traction across all other segments (Christensen et al., 2018). Encroachment patterns may not just follow a bottom-up approach as in Christensen's model (1997) but may also follow a top-down approach, where products are first introduced in the higher end of the market and then are expanded to the lower-end, too (Sood and Tellis, 2011). In particular, the current context and the pervasiveness of digital infrastructures (Autio et al., 2018) have enabled the encroachment speed of innovation to rise significantly although also increasing the relevance of the competitive setting the company is immersed in (Parry and Kawakami, 2017).

This wide and established body of literature can provide a glimpse of the complexity that characterizes the literature on the evolution of technological innovation. However, more recently, scholars have started to investigate how other sources of innovation can trigger the emergence and consequent evolution of innovation.

\section{Innovation of meaning: a different perspective on innovation}

For several years, innovation scholars have considered two primary sources of innovation: market needs and technological advancements (Howells, 1997). These two aspects have given birth to two prominent approaches companies can have to innovation, i.e., market pull and technology push (Di Stefano et al., 2012; Dosi, 1982; Von Hippel, 1976).

In the last decades, this dyadic relationship has been challenged, also considering other triggers to innovation. Over the last years, management scholars have investigated the relevance of product meanings in the innovation management discipline, giving rise to a growing body of literature (e.g., Dell'Era et al., 2017; Goto, 2017; Holt and Cameron, 2010; Norman and Verganti, 2014). In particular, to this regard Verganti (2009) adds a third perspective to the traditional market-pull and technology-push model (Di Stefano et al., 2012; Dosi, 1982; Von Hippel, 1976), introducing the so-called design-push approach, that encompasses the role of design in giving meaning to products and services, shifting the underlying customer motives for consumption (Belk, 1988; Holt, 1997; Holt and Cameron, 2010), i.e., the reason why people use or buy products and services (Verganti, 2009). This approach encompasses proposing radically new elements to the market as a result of an understanding of the underlying socio-cultural dynamics, generating new directions for innovation (Verganti, 2011). As argued by Holt and Cameron (2010), innovation shifting the socio-cultural paradigm leverages ideological opportunities to propose new cultural expressions to consumers. The socio-cultural setting and players outside the company's boundaries can provide significant contributions and play a key role in developing a new socio-cultural understanding (Verganti and Oberg, 2013). 
As a consequence to the introduction of a new dimension upon which companies can innovate, Verganti (2009) explores the interplay between innovation in product and service meanings and the technological dimension of innovation, arguing that, when radically new technologies and radically new meanings are embodied within a product, they constitute so-called technology epiphanies (Verganti, 2011; Dell'Era et al., 2017; Goto, 2017; Trabucchi et al., 2017). Consequently, companies need to reconsider both their business and development models to overcome their path dependency and embrace new meanings (Dell'Era et al., 2020). For example, the involvement of designers in the innovation process may aid in understanding the potentialities of new meanings embedded in a technology (Dell'Era et al., 2017; Magistretti and Dell'Era, 2019). Furthermore, observing new meanings proposed by new entrants may motivate companies to rethink the way they are working and to foster innovation of meaning in their field (Trabucchi et al., 2017). In the end, the role of interpreters and the chance to leverage on the innovative power of criticism is fundamental to pursue this kind of innovation (Morillo et al., 2015; Verganti, 2017).

Second, scholars have started considering the diffusion of meanings in the market by focusing on product languages in design-intensive industries (Dell'Era and Verganti, 2007), by observing the patterns of imitation and innovation of product languages as a firms' innovation strategy. Dell'Era et al. (2008) stress the importance of analyzing dominant product languages and understanding the state-of-the-art of the industry for firms to pursue a proactive - as opposed to reactive - innovation strategy by making proposals to the market.

Empirical evidence for the success of a proactive strategy in generating product proposals are proposed by Dell'Era and Verganti (2010): the authors prove that trendsetters who continually introduce new product meanings to the market also benefit from the best innovative performance. Further research (Dell'Era and Verganti, 2011) provides hints on how to forecast the evolution of new product meanings in design-intensive industries through an analysis based on the market's competitive setting, the firms' reputation and the marketing strategies they adopted.

\section{Research gap}

This brief literature overview displays a clear distinction between the technology and meaning domains of innovation. In the context of technological innovation, extant literature has paid significant attention to innovation dynamics within an industry, and the way different companies may play a role in letting a technology evolve until the definition of a dominant design. In the context of the innovation of meaning, instead, scholarly work has mainly focused on the way companies may pursue a "meaning-oriented" strategy, paying little attention to the industry dynamics and mainly focusing on design-intensive industries.

While extant work on the innovation of meaning (e.g., Verganti, 2011; Dell'Era et al., 2017; Goto, 2017) has mainly adopted a product-centric, firm-level perspective, this study aims at extending the innovation of meaning discourse to how its innovation dynamics unfold from an industry-level perspective, similarly to how previous studies on technological and functional innovation have described the innovation dynamics taking place within an industry (e.g., Sood and Tellis, 2005; Tushman et al., 1997; Utterback, 1993; Von Hippel, 1976). To this regard, building on these models, our study aims at shedding light on how innovation dynamics take place when also the innovation of meaning is involved. In other words, this study investigates the behavior of firms within an industry which have introduced innovations within their products and services as a response to those of competitors, comparing both the functional level and the meaning level.

As a consequence, we formulate the following research questions (RQs):

$R Q 1$. How do product/service meanings evolve within an industry? 
EJIM

25,6

RQ2. How do the innovation dynamics behave within a market when discontinuities (i.e., radical innovations in both meaning and technology) are introduced?

$R Q 2.1$. How do firms react to discontinuities introduced by other firms?

\section{$102 \quad$ Area of investigation and sampling}

Two primary drivers guided the definition of the empirical sampling to provide a relevant answer to the defined research questions. First, to better capture the evolution of innovation dynamics, we selected an industry where the underlying meaning has significantly evolved within a limited timeframe, so to facilitate historical data retrieval (e.g. Ghezzi et al., 2015). Second, we selected a relatively concentrated market to longitudinally study a limited number of companies while still capturing the overall industry perspective. After careful evaluation, the social media industry was selected as a promising empirical setting. The popularity of social media platforms has been growing steadily, reaching 3, 6bn users in 2016 from the less than 1 bn users of 2010, recording a growth of more than $360 \%$ in ten years, and it is projected to reach almost 4, 5bn users by 2025 (Clement, 2020).

The market has faced important shifts in the reason why users share content on social media since the first platform (i.e., LinkedIn) went live on May 5th, 2003. At that time, the reason why users used social media platforms was mainly to be reachable online. Since then, the meaning of the service has slowly shifted toward multiple reasons - why. For example, to share significant moments with one's network (e.g., Snapchat with "The fastest way to share a moment"), to keep in touch with friends, to express an opinion (e.g., Twitter with "It's what's happening"), or to get informed, to find inspiration, to shop.

The social media industry is a highly relatively-concentrated field-i.e., only a handful of players detain the majority of the market share. This characteristic allowed us to longitudinally reach almost the totality of the market since its existence, providing an overview of all relevant competitive dynamics. The high relative market concentration has consequently brought players to keep a high level of competitiveness, continually trying to innovate by expanding toward new functionalities and new meanings. The final sample is composed of the most popular social media platforms worldwide by reach (Clement, 2017): Facebook, Twitter, Linkedin, WhatsApp, Snapchat, Google +, Instagram, and Pinterest.

\section{Data gathering and database creation}

The data gathering process consisted of the construction of a database, identifying the innovations introduced by the eight companies. The longitudinal analysis considered 160 innovations, spanning across 14 years, from May 5, 2003 to June 21, 2017. In particular, the word "innovation" is used to define all the new user-side features introduced in the main service. The data gathering process has been strongly iterative: data have been gathered through different sources to ensure triangulation and comprehensiveness. The data collection has been carried out by tracing back to the sequence of events and announcements in each platform's history, using the platforms' press blogs and press releases, supplemented by the dedicated Wikipedia timeline and description pages. These sources were integrated and verified with articles from online news, explaining meanings and functionalities contained in each innovation, academic case studies and public interviews given by the platforms' founders. Table 1 summarizes the sources employed in the data collection process.

The classification process leveraged multiple articles and announcements regarding each single innovation. For each of the 160 innovations, three pieces of information were collected: (1) introduction date, (2) company and (3) description. The articles were then systematized through observation and judgment of: (4) the functional advancement introduced and (5) the 


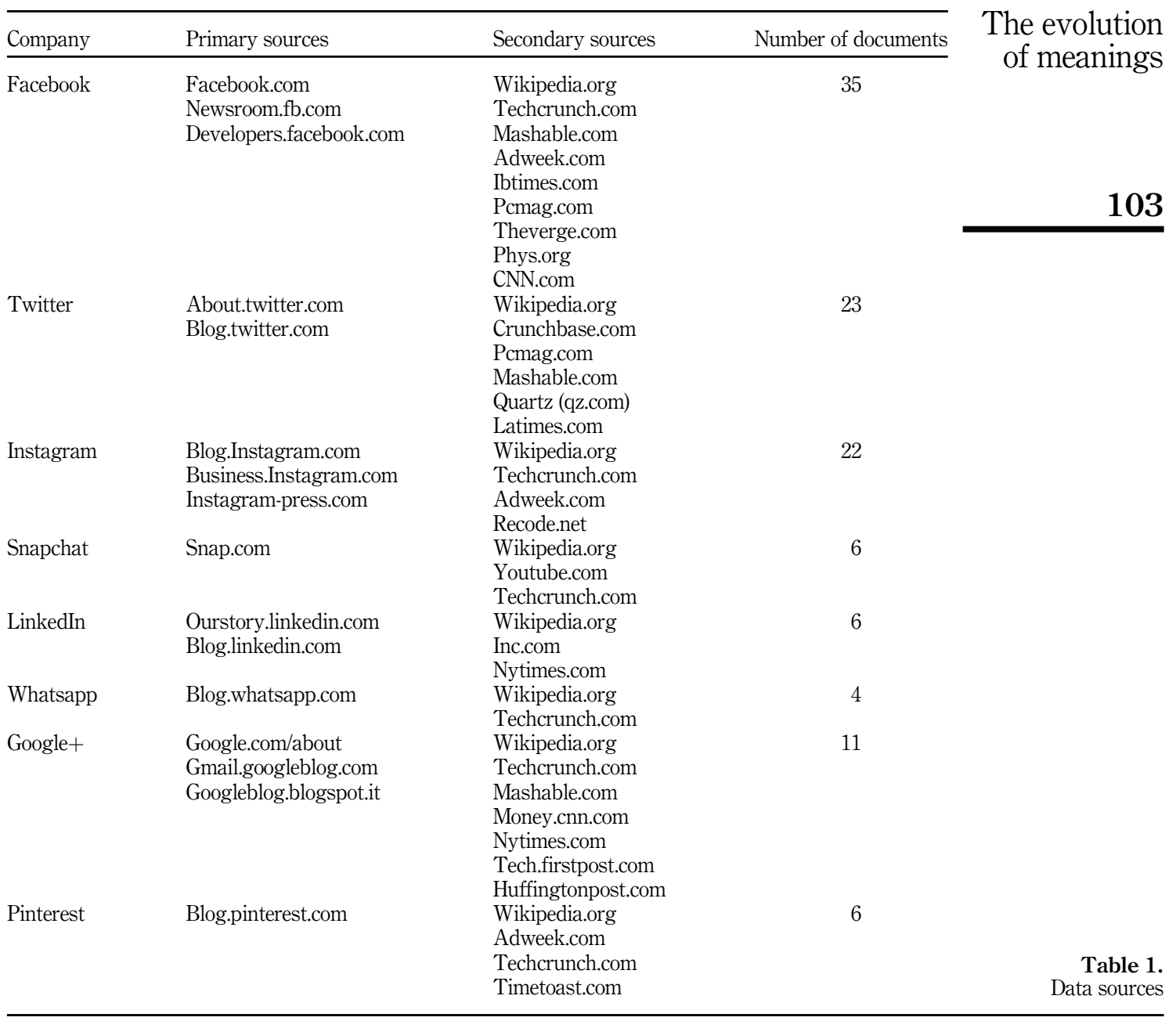

magnitude of change in the meaning-i.e., the reason why users use the platform. This analysis was performed keeping a market focus rather than a firm focus: when evaluating an innovation's radicalness, we assessed how new the feature was to the market and not to the company that introduced it. This choice was made to ensure consistency with the aim of this research to investigate the innovation dynamics at the industry level.

This thorough and punctual assessment provided the basis for classifying each of the 160 innovations through two different measures, so to account for the two dimensions of innovation following Verganti (2011): functional radicalness (FR) - intended as the extent to which an innovation is new to the market in terms of functionality and meaning radicalness (MR), intended as the extent to which the meaning, and thus the reason why users use the platform, has shifted from the extant meaning in the market. It is important to highlight how these measures aim to assess the radicalness of each innovation, rather than distinguishing between an incremental and a radical innovation. Indeed, the literature on this matter is often 
EJIM

25,6

104

focused on technology, linking the concept of radical innovation to technological breakthroughs. However, in the service domain, the concept of radical innovations refers to innovation in the configuration of activity chains or of the activities within the service itself (Sawhney et al., 2005).

Table 2 provides an excerpt of the database and the five dimensions through which each of the innovations has been characterized. The scores scale ranges from 0 to 4 (from 0: no innovation-pure imitation to 4: functional turnaround or 4: Radical shift in the reason why users use the service). As the literature suggests (e.g., Verganti and Öberg, 2013), product and service meanings are proposals made by companies to customers, the scores were assigned evaluating the radicalness of the meaning proposed, rather than perceived. For example, the innovation "Snapchat Stories" (see Table 2) introduced in October 2013 has been evaluated to have a FR score of 3 as the new feature encompassed associating a series of pictures that would be public for only 24 hours with each users, coupled with a MR score of 3 as it provided users a new reason to use Snapchat, such as sharing low-quality and quick pictures with friends. Similarly, the feature "My Day", introduced by Facebook in August 2016 to share disappearing pictures with Facebook Messenger contacts for 24 hours, has been evaluated with lower functional and meaning radicalness (both having a score of 1 ). While the first innovation marked the introduction of a new meaning in the service use and a significant addition in functionality, the second only provides an additional reason to use Facebook for its users, i.e., a novelty for the platform, but not for the market, with no significant functional advancement.

To ensure inter-rater reliability (Armstrong et al., 1997), a panel of three experts in designdriven innovation validated the scores. Three independent scholars with strong knowledge in innovation dynamics and innovation of meaning were asked to classify a subsample of the innovations (see for example Trabucchi et al., 2019). The validation was done on a random subsample, representing $13 \%$ of the total entries. The classification given independently by

\begin{tabular}{|c|c|c|c|c|c|}
\hline Innovation & Date & Company & Description & $\begin{array}{c}\text { FR } \\
\text { score }\end{array}$ & $\begin{array}{c}\text { MR } \\
\text { score }\end{array}$ \\
\hline Snapchat launch & Jul-11 & Snapchat & $\begin{array}{l}\text { Snapchat launches as an app to send contacts } \\
\text { photos that disappear after being seen }\end{array}$ & 1 & 4 \\
\hline Snapchat stories & $\begin{array}{l}\text { Oct- } \\
13\end{array}$ & Snapchat & $\begin{array}{l}\text { Launch of stories, a space to publicly share } \\
\text { pictures lasting for } 24 \mathrm{~h} \text { that can be replayed } \\
\text { as many times as the viewer wants }\end{array}$ & 3 & 3 \\
\hline $\begin{array}{l}\text { Disappearing } \\
\text { messages }\end{array}$ & $\begin{array}{l}\text { May- } \\
14\end{array}$ & Snapchat & $\begin{array}{l}\text { Possibility to send disappearing text and } \\
\text { pictures from the phone's gallery introduced }\end{array}$ & 2 & 2 \\
\hline Instagram Stories & $\begin{array}{l}\text { Aug- } \\
16\end{array}$ & Instagram & $\begin{array}{l}\text { Users get the possibility to share pictures that } \\
\text { disappear after } 24 \mathrm{~h} \text { with their followers, as } \\
\text { well as see other users' "Stories" }\end{array}$ & 2 & 3 \\
\hline $\begin{array}{l}\text { Facebook "my } \\
\text { day" }\end{array}$ & $\begin{array}{l}\text { Sep- } \\
16\end{array}$ & Facebook & $\begin{array}{l}\text { Users can publicly share pictures that } \\
\text { disappear after } 24 \mathrm{~h} \text { on Facebook Messenger } \\
\text { through a function called "my day" }\end{array}$ & 1 & 1 \\
\hline $\begin{array}{l}\text { Private } \\
\text { disappearing } \\
\text { content }\end{array}$ & $\begin{array}{l}\text { Nov- } \\
16\end{array}$ & Instagram & $\begin{array}{l}\text { Users can privately send each other } \\
\text { disappearing photos and videos }\end{array}$ & 0 & 0 \\
\hline Facebook stories & $\begin{array}{l}\text { Jan- } \\
17\end{array}$ & Facebook & $\begin{array}{l}\text { Facebook Stories introduced as pictures that } \\
\text { can be shared with Facebook friends lasting } \\
24 \mathrm{~h}\end{array}$ & 0 & 0 \\
\hline Whatsapp status & $\begin{array}{l}\text { Feb- } \\
17\end{array}$ & Whatsapp & $\begin{array}{l}\text { "Status" feature introduced, giving users the } \\
\text { possibility to share photos with Whatsapp } \\
\text { contacts lasting } 24 \mathrm{~h}\end{array}$ & 1 & 1 \\
\hline
\end{tabular}

Table 2.

Excerpt of the database of innovations 
each expert had a $94 \%$ overlap with that performed by the authors, depicting excellent reliability of the codification protocol employed.

\section{Data analysis}

Following the suggestions provided by previous contributors to the observation of innovations as innovation streams (Tushman et al., 1997), we investigated the presence of subsystems within the sample. As a consequence, we identified 12 innovation streams, defined as sets of subsystems of innovation that concern comparable features of a given product or service. For example, the innovations listed in Table 2 represent an excerpt of the innovation stream named "Ephemeral content" as all of the innovations contained in the stream encompass content that is meant to disappear within a specific amount or time, such as pictures or text messages that disappear after being seen, photos and videos that are visible to followers for 24 hours only or temporary user pictures to honor an event or support a cause.

Each stream was then analyzed to investigate the innovation dynamics taking place within it. Leveraging on Verganti's (2011) framework, for each stream, the initiatives were mapped on the two dimensions of radicalness -meaning radicalness (MR) and functional radicalness (FR). As in Verganti's matrix (2011), four quadrants emerge: the incremental quadrant (FR and $\mathrm{MR} \leq 2)$; the radical function quadrant ( $\mathrm{FR}>2$ and $\mathrm{MR} \leq 2)$; the radical meaning quadrant ( $\mathrm{FR} \leq 2$ and $\mathrm{MR}>2$ ) and the epiphany quadrant $(\mathrm{FR}>2$ and $\mathrm{MR}>2)$.

Each innovation has been represented in the matrix representing its innovation stream. at the intersection of its scores that introduced it. Then, numbered arrows were drawn to describe the chronological path, followed by the innovations. Finally, the arrows have been colored to distinguish between the different cycles (Tushman et al., 1997): whenever a radical innovation takes place right after an incremental innovation (or a series of), a new cycle begins and continues until the same condition is verified again. To keep track of new "cycles", the arrows' color shift whenever a radical innovation takes place (steps 4 and 8). As an example, Figure 1 represents each of the innovations belonging to the "Ephemeral content" innovation stream in the matrix.
The evolution of meanings

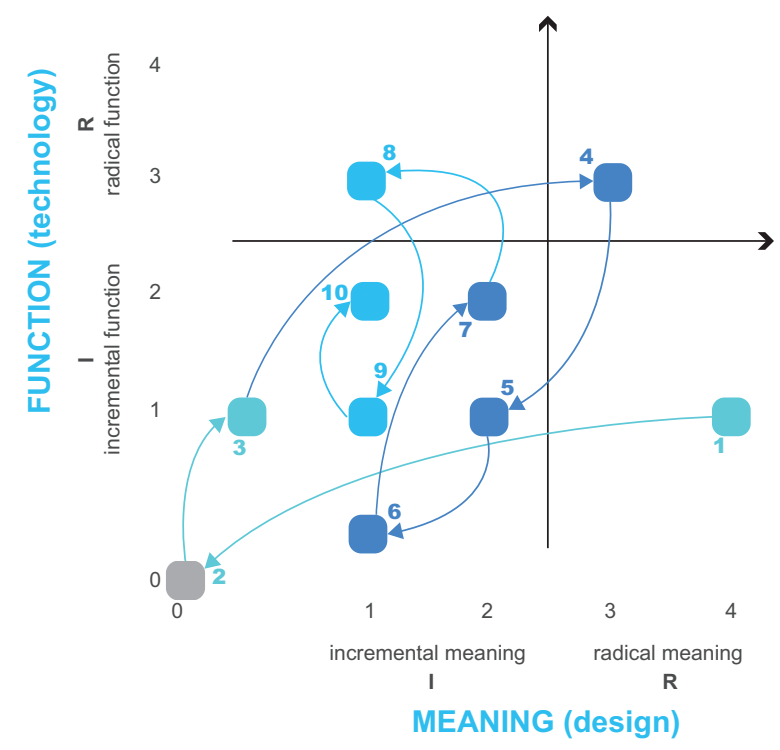

Figure 1 .

Example of data analysis in the "Ephemeral content" innovation stream 
EJIM

25,6

106
The matrices were visually inspected to understand the distribution of innovations across the quadrants and the innovation strategies adopted by all different players. The streams were then grouped, identifying which quadrants of the matrix hosted most innovations and the path followed by the innovations across the four quadrants.

Finally, the first mover's and followers' strategies were analyzed to investigate the diffusion of both functionalities and meanings along the period of analysis.

In addition to plotting the results on the matrix, we analyzed the 12 innovation streams through descriptive statistics (as shown in Table 5 in the results section), to understand common patterns and differences between each of the streams. On the one hand, we observed the competitive dynamics taking place between players, such as (1) the number of followers in each innovation stream, (2) the average number of players that took part to each cycle-i.e., following a radical innovation on either dimension with incremental ones, (3) the number of cycles that took place in each innovation stream, (4) the number of cycles that did not see incremental innovations following it and (5) the average duration of the cycles. These data were used to make better sense of the dynamics taking place into each innovation stream and facilitate interpretation, giving the authors an overview on the 12 innovations streams.

\section{Results}

The 12 innovation streams identified by leveraging on the definition provided by the literature (Tushman et al., 1997) are summarized in Table 3. Building on these 12 innovation streams, we structure the following section responding to our RQs.

First, the twelve innovation streams are analyzed according to the innovation approach that characterizes them, i.e., whether innovation is driven by technology or by meanings (Verganti, 2011). Second, the streams are analyzed according to their internal innovation dynamics, representing the evolution of innovation within the same stream by relying on cyclical models of innovation (Tushman et al., 1997).

\section{Innovation approaches}

For each innovation stream, the dynamics and the typologies of improvements introduced by the different players lead the definition of the dominant innovation approach within each stream. Namely, we identified three different innovation approaches out of the 12 innovation streams investigated: (1) design-oriented, (2) technology-oriented and (3) balanced (see Figure 2).

Design-oriented. Three streams (25\% of the overall sample) display a high incidence of initiatives in the bottom-right quadrant: the radical meaning/incremental functional innovation quadrant (R-I) (Figure 3). These streams have been identified as design-oriented because of the predominant approach to innovation, mainly focusing on the radical meaningincremental functional innovation strategy.

In particular, the three innovation streams adopting this approach are (1) social media as news sources, (2) ephemeral content and (3) reactions. Entry to the stream happens almost exclusively in the bottom two quadrants, either radically operating on the meaning and incrementally on the functionality, or incrementally on both dimensions. Furthermore, it is interesting to notice how stream-opening innovations have a score of 4 in $\mathrm{MR}$, and incremental (1 or 2) in FR. Therefore, design-oriented streams are more likely to see first movers following a design-push strategy.

For example, the innovation stream "Ephemeral content" (refer to Table 2 for an excerpt of the innovations included in the stream) represents a design-oriented stream in that, after being opened by a radical innovation in the reason why users would use a social media platform - i.e., for sharing with each other quick and low-quality pictures that would 


\begin{tabular}{|c|c|c|c|c|c|}
\hline $\begin{array}{l}\text { Innovation } \\
\text { stream }\end{array}$ & Description & Example & $\begin{array}{l}\text { Starting } \\
\text { date }\end{array}$ & $\begin{array}{l}\text { Number of } \\
\text { innovations }\end{array}$ & $\begin{array}{l}\text { The evolution } \\
\text { of meanings }\end{array}$ \\
\hline Basic sharing & $\begin{array}{l}\text { Innovations that make up the } \\
\text { basic sharing functions of a } \\
\text { social media platform }\end{array}$ & $\begin{array}{l}\text { Possibility to share posts } \\
\text { on Facebook's "Wall” }\end{array}$ & May 2003 & 28 & \\
\hline Messaging & $\begin{array}{l}\text { Innovations related to instant } \\
\text { private messaging between } \\
\text { users of a social media } \\
\text { platform }\end{array}$ & $\begin{array}{l}\text { Introduction of a private } \\
\text { messaging function on } \\
\text { Facebook }\end{array}$ & $\begin{array}{l}\text { November } \\
2007\end{array}$ & 19 & 107 \\
\hline $\begin{array}{l}\text { Indexing and } \\
\text { collecting }\end{array}$ & $\begin{array}{l}\text { Innovations enabling the } \\
\text { organization and saving of } \\
\text { items }\end{array}$ & $\begin{array}{l}\text { Introduction of hashtags } \\
\text { (\#) by Twitter }\end{array}$ & $\begin{array}{l}\text { August } \\
2007\end{array}$ & 11 & \\
\hline $\begin{array}{l}\text { Mobile } \\
\text { technologies }\end{array}$ & $\begin{array}{l}\text { Entries related to the } \\
\text { expansion of the platform to } \\
\text { mobile devices }\end{array}$ & $\begin{array}{l}\text { Launch of Linkedin } \\
\text { mobile app }\end{array}$ & $\begin{array}{l}\text { January } \\
2007\end{array}$ & 13 & \\
\hline $\begin{array}{l}\text { Social media as } \\
\text { news sources }\end{array}$ & $\begin{array}{l}\text { Innovations aiming at making } \\
\text { social media a news outlet, a } \\
\text { reliable source where the } \\
\text { community gets information } \\
\text { from }\end{array}$ & $\begin{array}{l}\text { Possibility to share } \\
\text { external links on } \\
\text { Facebook }\end{array}$ & $\begin{array}{l}\text { September } \\
2008\end{array}$ & 11 & \\
\hline $\begin{array}{l}\text { Conversion } \\
\text { into purchases }\end{array}$ & $\begin{array}{l}\text { Innovations apt at creating } \\
\text { making social media } \\
\text { platforms closer to e- } \\
\text { commerce }\end{array}$ & $\begin{array}{l}\text { Introduction of shoppable } \\
\text { photo tags that redirect to } \\
\text { seller websites on } \\
\text { Instagram }\end{array}$ & $\begin{array}{l}\text { December } \\
2013\end{array}$ & 12 & \\
\hline Live content & $\begin{array}{l}\text { Innovations involving the } \\
\text { process of sharing content in } \\
\text { real-time }\end{array}$ & $\begin{array}{l}\text { Introduction of live } \\
\text { streaming of stories on } \\
\text { Snapchat }\end{array}$ & March 2006 & 6 & \\
\hline $\begin{array}{l}\text { Location } \\
\text { services }\end{array}$ & $\begin{array}{l}\text { Advancements involving GPS } \\
\text { and geographic locations }\end{array}$ & $\begin{array}{l}\text { Possibility to } \\
\text { geographically tag } \\
\text { Instagram photos }\end{array}$ & $\begin{array}{l}\text { February } \\
2010\end{array}$ & 9 & \\
\hline Video content & $\begin{array}{l}\text { Innovations involving } \\
\text { sharing of videos as self- } \\
\text { standing content }\end{array}$ & $\begin{array}{l}\text { Launch of Vine video app } \\
\text { by Twitter }\end{array}$ & $\begin{array}{l}\text { October } \\
2006\end{array}$ & 9 & \\
\hline $\begin{array}{l}\text { Ephemeral } \\
\text { content }\end{array}$ & $\begin{array}{l}\text { Contents related to } \\
\text { disappearing pictures and } \\
\text { videos, the conversational and } \\
\text { quality-regardless of use of } \\
\text { social media }\end{array}$ & $\begin{array}{l}\text { Introduction of Snapchat } \\
\text { Stories enabling users to } \\
\text { share pictures lasting } 24 \mathrm{~h}\end{array}$ & July 2011 & 16 & \\
\hline $\begin{array}{l}\text { Connecting to } \\
\text { anybody }\end{array}$ & $\begin{array}{l}\text { Advancements apt at creating } \\
\text { public profiles and pages, } \\
\text { such as business or celebrities, } \\
\text { giving the community the } \\
\text { potential to reach out to } \\
\text { anybody }\end{array}$ & $\begin{array}{l}\text { Making Linkedin profiles } \\
\text { public }\end{array}$ & $\begin{array}{l}\text { February } \\
2006\end{array}$ & 11 & \\
\hline Reactions & $\begin{array}{l}\text { Advancements related to the } \\
\text { interactions users can have } \\
\text { with posts shared by other } \\
\text { users }\end{array}$ & $\begin{array}{l}\text { Instagram eliminating the } \\
\text { possibility to view the } \\
\text { number of likes in a post }\end{array}$ & June 2008 & 17 & $\begin{array}{l}\text { Table 3. } \\
\text { The } 12 \text { innovation } \\
\text { streams identified }\end{array}$ \\
\hline
\end{tabular}

disappear after being opened - it sets a new standard in the market, seeing the following of several different platforms that decided to adopt the same paradigm. As this "ephemeral" kind of sharing became widespread, the following innovations introduced predominantly leveraged the meaning dimension of innovation. For example, the introduction of the "Stories" function by Instagram allowed users to share (and on the other hand, see) moments of their day for 24 hours in parallel to the "steady" content posted on their feed. Through this 
EJIM 25,6
Table 4.

Relationship between innovation approach and entry strategy of each stream

\begin{tabular}{lll} 
Innovation approach & Innovation stream & Entry \\
\hline Balanced & Basic sharing & Strategy \\
& Messaging & Technology epiphany \\
& Indexing and Collecting & Technology epiphany \\
& Mobile technologies & Technology epiphany \\
& Conversion into purchases & Technology epiphany \\
& Live content & Technology epiphany \\
& Location services & Incremental \\
& Connecting to anybody & Technology epiphany \\
Design-Oriented & Ephemeral content & Design-driven \\
& Social media as news sources & Design-driven \\
Technology-Oriented & Reactions & Design-driven \\
& Video content & Technology-push
\end{tabular}

Technology-Oriented innovation, the company offered its users a new glimpse into influencers' and friends' everyday lives, giving them a new reason to use the app.

Technology-oriented. In the second innovation approach, the majority of initiatives are present in the upper area of the matrix. In these areas, radically new functions are coupled with either incremental or radical meaning changes (I-R and R-R), representing what was defined as a technology-oriented approach (Figure 4).

Only one innovation stream ( $8 \%$ of the total sample) follows this approach - the one based on video content; for this reason, making a strong case about this innovation approach is difficult. Entry to the stream happens almost exclusively in the top two quadrants, either radically operating on the functionality and incrementally on the meaning, or incrementally on both directions. The first mover opened the stream with a $0-2$ innovation ( 0 in MR and 2 in FR). This shows how, despite not radical, the innovation was a functional advancement rather than a shift in meaning.

This innovation stream has predominantly seen innovations in the functional aspects of the apps, including advances in video duration and usability - e.g., Snapchat's integration of videos to their disappearing content possibilities.

Balanced. The last innovation approach embodies the majority of the sample $(67 \%)$. These innovation streams are labeled as balanced. A relevant number (in some instances, even totality) of initiatives lies between the R-R and I-I quadrants (Figure 5). This distribution depicts and interestingly high number of technology epiphanies (R-R quadrant) (Verganti, 2011) followed by their imitations (I-I quadrant). The innovation streams following this approach differ slightly from one another. In some cases, the R-I (radical meaning incremental function) quadrant is also populated. In contrast, in some other cases, initiatives are present in both $\mathrm{R}-\mathrm{I}$ and $\mathrm{I}-\mathrm{R}$ quadrants and again other times the two quadrants are empty. This innovation stream also has an outlier: its configuration is conceptually coherent with the approach, but it does not present the majority of initiatives in the epiphany quadrant. For this reason, it will not be commented on any further in the text.

Eight innovation streams follow this innovation approach: (1) mobile technologies, (2) indexing and collecting, (3) messaging, (4) conversion into purchases, (5) basic sharing, (6) connecting to anybody, (7) live content, and (8) location services. Entry to the stream happens either with an epiphany or through imitation, while the first movers always open the stream with an epiphany.

For example, the innovation stream "Conversion into purchases" has been classified as one of the balanced streams, in that it has seen a continuous shift between technology epiphanies and consequent cycles of incremental innovations and imitations. For example, after the 


\begin{tabular}{|c|c|c|c|c|c|c|c|c|}
\hline $\begin{array}{l}\text { Innovation } \\
\text { approach }\end{array}$ & $\begin{array}{l}\text { Innovation } \\
\text { stream }\end{array}$ & $\begin{array}{l}\text { Number of } \\
\text { followers } \\
\text { (companies) }\end{array}$ & $\begin{array}{c}\text { Average } \\
\text { number } \\
\text { of } \\
\text { players } \\
\text { per cycle } \\
\end{array}$ & $\begin{array}{l}\text { Number } \\
\text { of cycles }\end{array}$ & $\begin{array}{l}\text { Number of } \\
\text { cycles } \\
\text { with just } \\
\text { one } \\
\text { (radical) } \\
\text { innovation }\end{array}$ & $\begin{array}{c}\text { Average } \\
\text { number of } \\
\text { innovations } \\
\text { per cycle }\end{array}$ & $\begin{array}{l}\text { Average } \\
\text { duration } \\
\text { of the } \\
\text { cycle } \\
\text { [months] }\end{array}$ & $\begin{array}{l}\text { The evolution } \\
\text { of meanings }\end{array}$ \\
\hline \multirow[t]{10}{*}{ Balanced } & $\begin{array}{l}\text { Basic } \\
\text { sharing }\end{array}$ & 4.0 & 2.0 & 10.0 & 4.0 & 3.6 & 24.2 & 109 \\
\hline & Messaging & 5.0 & 3.0 & 9.0 & 5.0 & 3.5 & 24.3 & \\
\hline & $\begin{array}{l}\text { Indexing } \\
\text { and }\end{array}$ & 4.0 & 3.0 & 3.0 & 1.0 & 5.0 & 84.0 & \\
\hline & $\begin{array}{l}\text { Collecting } \\
\text { Mobile } \\
\text { technologies }\end{array}$ & 7.0 & 2.8 & 5.0 & 1.0 & 2.8 & 29.0 & \\
\hline & $\begin{array}{l}\text { Conversion } \\
\text { into } \\
\text { purchases }\end{array}$ & 3.0 & 2.3 & 4.0 & 1.0 & 4.0 & 17.5 & \\
\hline & Live content & 3.0 & 2.0 & 4.0 & 2.0 & 2.0 & 12.0 & \\
\hline & $\begin{array}{l}\text { Location } \\
\text { services }\end{array}$ & 3.0 & 2.3 & 4.0 & 1.0 & 4.0 & 17.5 & \\
\hline & $\begin{array}{l}\text { Connecting } \\
\text { to anybody }\end{array}$ & 5.0 & 4.0 & 2.0 & 0.0 & 4.5 & 57.0 & \\
\hline & Average & 4.25 & 2.49 & 5.13 & 1.88 & 3.68 & 33.19 & \\
\hline & $\begin{array}{l}\text { Standard } \\
\text { deviation }\end{array}$ & 1.39 & 0.44 & 2.85 & 1.73 & 0.95 & 24.69 & \\
\hline \multirow[t]{5}{*}{$\begin{array}{l}\text { Design- } \\
\text { Oriented }\end{array}$} & $\begin{array}{l}\text { Ephemeral } \\
\text { content }\end{array}$ & 3.0 & 2.3 & 3.0 & 0.0 & 4.3 & 30.5 & \\
\hline & $\begin{array}{l}\text { Social media } \\
\text { as news } \\
\text { sources }\end{array}$ & 3.0 & 2.0 & 5.0 & 1.0 & 2.7 & 28.3 & \\
\hline & Reactions & 5.0 & 3.5 & 2.0 & 1.0 & 8.0 & 92.0 & \\
\hline & Average & 3.67 & 2.60 & 3.33 & 0.67 & 5.00 & 50.27 & \\
\hline & $\begin{array}{l}\text { Standard } \\
\text { deviation }\end{array}$ & 1.15 & 0.79 & 1.53 & 0.58 & 2.72 & 36.16 & \\
\hline \multirow{2}{*}{$\begin{array}{l}\text { Technology- } \\
\text { Oriented }\end{array}$} & Video & 4.0 & 3.0 & 2.0 & 1.0 & 4.0 & 31.0 & \\
\hline & Average & 4.0 & 3.0 & 2.0 & 1.0 & 4.0 & 31.0 & \\
\hline \multirow{2}{*}{$\begin{array}{l}\text { Overall } \\
\text { statistics } \\
\text { along the } 12 \\
\text { streams }\end{array}$} & Average & 4.08 & 2.56 & 4.42 & 1.50 & 4.03 & 37.28 & \\
\hline & $\begin{array}{l}\text { Standard } \\
\text { deviation }\end{array}$ & 1.24 & 0.52 & 2.61 & 1.51 & 1.50 & 26.22 & $\begin{array}{r}\text { Table } 5 . \\
\text { Overall analysis of the } \\
\text { twelve Innovation } \\
\text { Streams identified }\end{array}$ \\
\hline
\end{tabular}

introduction of "Buyable pins" on Pinterest, where users could click on the content they saved and be directly sent to the seller's website and purchase the product, other platforms have adopted the same possibility. For example, Instagram's clickable "Photo tags" on Instagram picture would similarly direct users to purchasing products on the seller's website.

\section{Innovation dynamics}

The analysis of the innovation matrix reveals different entry strategies, which can be classified as follows: (1) design-driven first mover, the firm opens a new innovation stream through a radical innovation of meaning, building on existing functionalities; (2) incremental first mover, the firm launches a new innovation stream, likely unknowingly, through an 


\section{EJIM \\ 25,6}

110

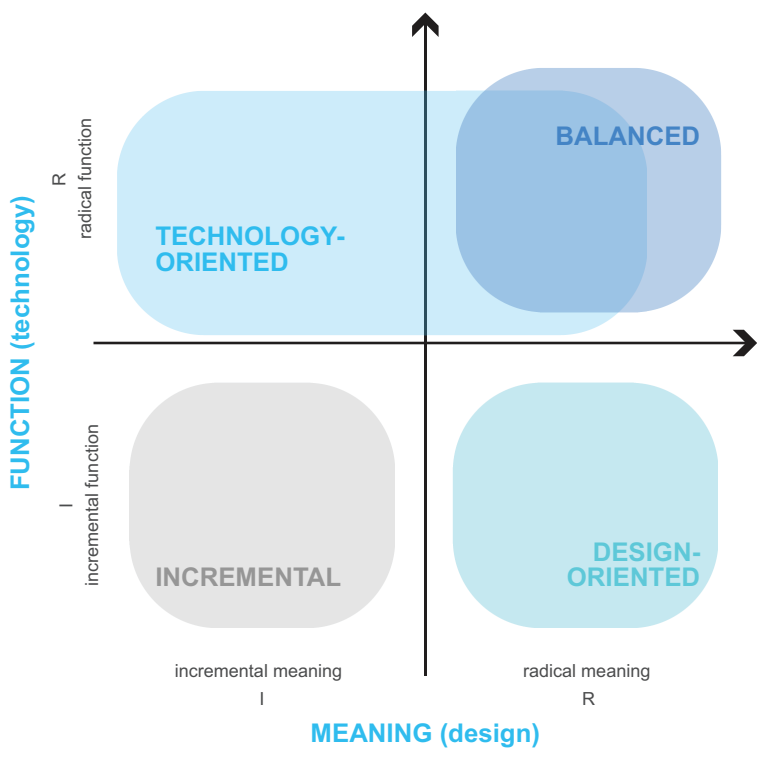

Figure 2.

Innovation approaches (adapted from

Verganti, 2011)

Figure 3.

Distribution of innovation in designoriented streams

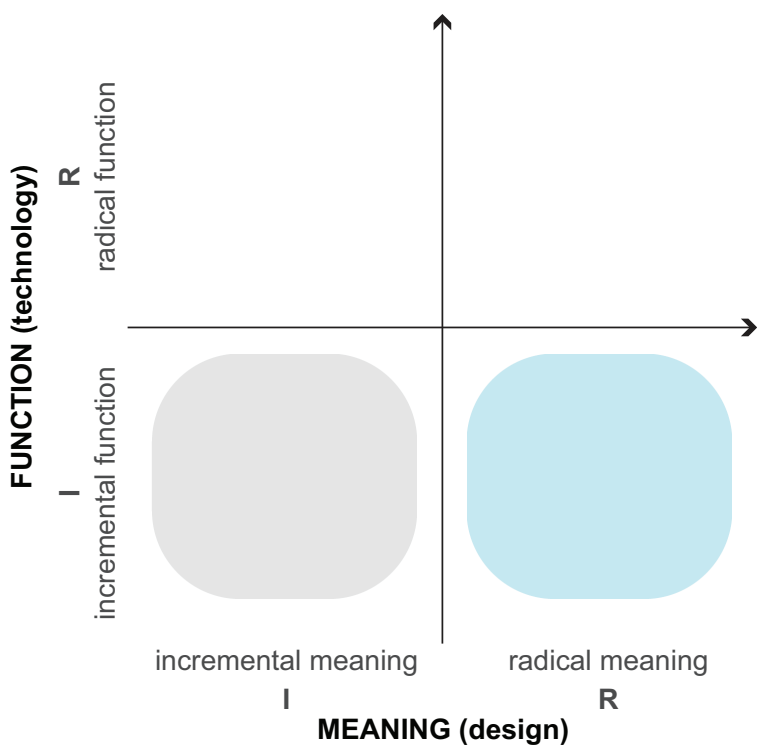

incremental functional advancement; (3) technology epiphany first mover, the firm opens a new innovation stream through a technology epiphany (summarized in Table 4).

Innovation streams that had a design-driven first mover all adopt a design-oriented innovation approach; for example, looking at the "Ephemeral content" innovation stream (see Table 2 and Figure 1), the innovations introduced and the origin of the stream lie mostly in shifts in the reason why users share on a given social media platform - i.e., sharing lowerquality images from their everyday life as they will disappear - rather than leveraging on 


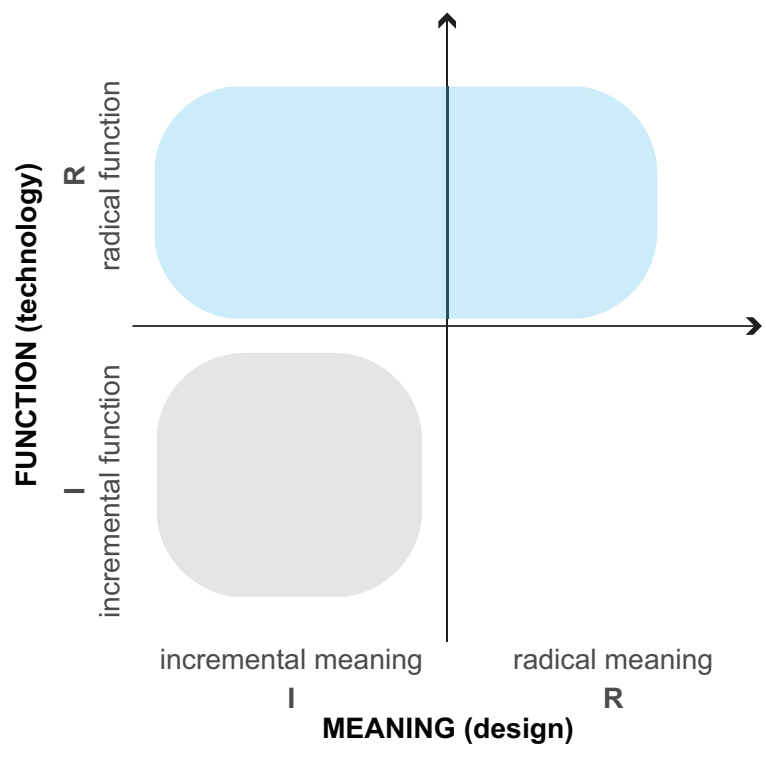

The evolution of meanings

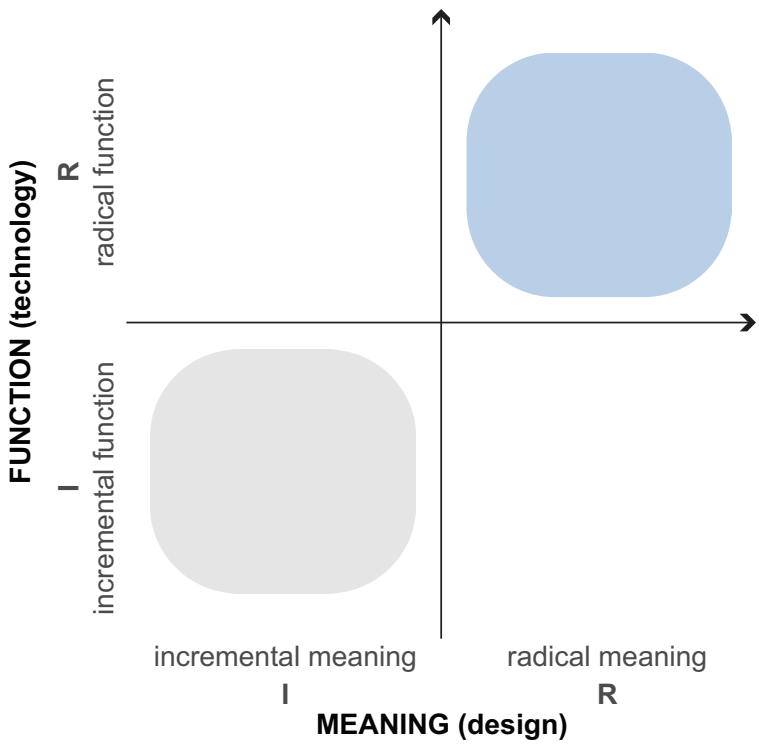

Figure 5.

Distribution of innovation in balanced streams

functional novelties. Innovation streams with a technology epiphany first mover all later result in balanced streams; an example is represented by the "Conversion into purchases" innovation stream, which has leveraged both a functional innovation - i.e., adding e-commerce functionalities to social media platforms - and an innovation of meaning - i.e., users visiting social media platforms to shop for specific items - to be created and furtherly imitated by other players in the market. Finally, streams with a technology-push first mover, seem to result in a technology-oriented setting, such as the "Video content" innovation stream, 
EJIM

25,6

112 born from the possibility of sharing videos to Facebook, which followed up with continuous and consequent functional innovations into each of the platforms involved.

The analysis draws a clear link between the entry strategy and the overall innovation approach followed by each stream.

Furthermore, the analysis of the dataset reveals even broader information (summarized in Table 5). The sample of 160 innovations sees the participation of eight players in total. However, only four players (with a standard deviation of 1,24), on average, take part in each innovation stream. This value is quite stable across the twelve innovation streams, with a slightly lower number of players in the design-oriented streams (average: 3,67 ). Moreover, an even smaller portion of the players takes part in the single cycles within the stream: on average 2,49 out of 4,25 for the balanced streams and 2,60 out of 3,67 in the designed-oriented ones. This behavior is also reflected in the technology-oriented stream (on average three out of four), although it is not possible to consider an average behavior.

The number of cycles - calculated as the number of radical innovations introduced after the beginning of the stream - is 4,42 , considering a higher difference between the balanced and the design-oriented streams. The number of cycles following the second approach is lower than in the first $(3,33$ versus 5,13$)$. Interestingly, the number of cycles with just one (radical innovation) - i.e., immediately followed by the start of a new cycle introduced by a new radical innovation - is significantly higher in balanced streams $(1,88)$ than in design-oriented ones $(0,69)$. Nevertheless, the average number of innovations per cycle is slightly lower in balanced streams $(3,68$ versus 5,00$)$. The same observation is confirmed by the average cycle duration, being shorter for balanced streams (33,19 months) as compared to design-oriented ones (50,27 months), although in both cases, the standard deviations are significantly high.

Overall, it is interesting to observe how, on average, four companies are involved in all the streams (representing half of the considered sample), relying on approximately 4,5 radical innovations each (thus, cycles), making each cycle particularly brief in terms of number of incremental innovations (approximately four) and lasting on average three years.

\section{Discussion}

Our results explore the innovation dynamics where a meaning dimension of innovation exists, along with the technological dimension, and is relevant in defining a model for the observation of innovation. First, the results highlight aspects that challenge existing models. Moving from a purely technological perspective to a mixed perspective that encompasses both meanings and functionalities urges the need to update the traditional functional innovation models (e.g., Christensen and Bower, 1996; Tushman et al., 1997) that represent new technologies as transient paradigms, constantly undergoing replacement by new generations entering the market. Second, the observation of two different dimensions of innovation at the same time underlines significant differences from previous models. The starting point of the analysis consisted in the identification of 12 different innovation streams within the same product: social media platforms. This, on the one hand, is inherent in the selected industry and product type: digital platforms give companies the possibility to leverage on their basic architecture to foster innovation in multiple, coexisting directions (Gawer and Cusumano, 2014). On the other hand, given the co-creational nature of the service experience (Ramaswamy and Ozcan, 2018), users may take part to the innovation of the service itself by customizing the way they experience it and autonomously introducing innovations according to their needs (Oliveira and von Hippel, 2011). As product and service meanings are proposals made by companies to their customers that leverage emerging sociocultural trends (Verganti and Öberg, 2013), this autonomous way of experiencing services and user participation in their innovation process may be of particular relevance when dealing with service meanings leveraging a co-creational logic (Artusi and Bellini, 2020a). 
These relevant differences hint for the need to update the existing models on innovation dynamics. As opposed to traditional models (Tushman et al., 1997) that only observe one dimension of innovation and iteratively build on previous work, the opportunity to leverage on two dimensions of innovation lets different innovation streams co-exist and simultaneously evolve in the market (Figure 6). This is consistent with the interpretation of product meanings as proposals that companies make to users (Verganti and Öberg, 2013). Users may or may not accept them, pushing the market players to work on different levels (Trabucchi et al., 2017) building modular designs that allow tailoring the product to each user's needs. To this extent, the chance to leverage a digital infrastructure- as in the case of the social media industry - enables the co-existence of different types of features within the same service, working as a platform (Gawer and Cusumano, 2014) where, various meanings can be created relying on scope economies, exploiting the value of different innovation streams for the same set of customers.

This section considers two main perspectives: (1) the triggers to new innovation streams as compared to traditional dynamic models and (2) the dynamics taking place within a single innovation stream as compared to traditional models, now considering the interplay between functionalities and meanings.

A first difference from the cyclical model presented by Tushman et al. (1997) consists of the triggers to the generation of new innovation streams. Existing models in innovation dynamics consider technological discontinuities or breakthroughs as the starting point of every new cycle. A remarkable observation resulting from our analysis of the social media industry is how the innovation of meaning can play a relevant role in the industry's dynamics. These triggers, alone or combined with a technological change, can foster innovation within the single stream, promote the beginning of new cycles or even give rise to new innovation streams. As a result, the observation of innovation dynamics within each innovation stream displays the coexistence of both functionality-based innovations and innovations based purely on a shift in meaning. This finding is consistent with previous research, confirming the existence of three different forms of innovation - i.e., technology push (Dosi, 1982), designdriven (Verganti, 2011), and market pull (Von Hippel, 1976), involving different aspects driving the introduction of an innovation.

Furthermore, it appears that, in design-oriented streams, the kind of innovation that gives rise to a new stream guides the innovation approach of the entire stream. In contrast, those streams started through a technology epiphany evolve in different directions - relying on both incremental innovations in functions and/or in meanings - resulting in an overall balanced strategy.

Traditional models on innovation dynamics (e.g., Abernathy and Utterback, 1978; Tushman et al., 1997) portray the existence of a series of distinct phases: an era of ferment triggered by a discontinuity, followed by an incremental phase triggered by the emergence of a dominant design. The proposed analysis of the 12 innovation streams can contribute to innovation theory by enriching the models mentioned above: extending them on the one hand, while challenging some of their underlying assumptions on the other.

Every innovation stream contains, on average, four cycles, regardless of the stream's nature or whether the radical improvement involves functionalities or meanings. Previous studies were able to propose a clear distinction between the era of ferment and the era of incremental reworks. This phenomenon is hardly observable in this case as cycles are significantly shorter (including four innovations on average), leading them to be too short and without enough time to allow the emergence of a dominant design. This finding challenges previous studies that focused only on the technological domain (e.g., Abernathy and Utterback, 1978; Anderson and Tushman, 1990; Tushman and Anderson, 1986; Tushman et al., 1997).

The main difference is related to the clear distinction between the era of ferment and the era of incremental change, as previous models (Anderson and Tushman, 1990; Tushman et al., 1997) considered the two eras as separated by the emergence of a dominant design.
The evolution of meanings 


\section{EJIM \\ 25,6}

114

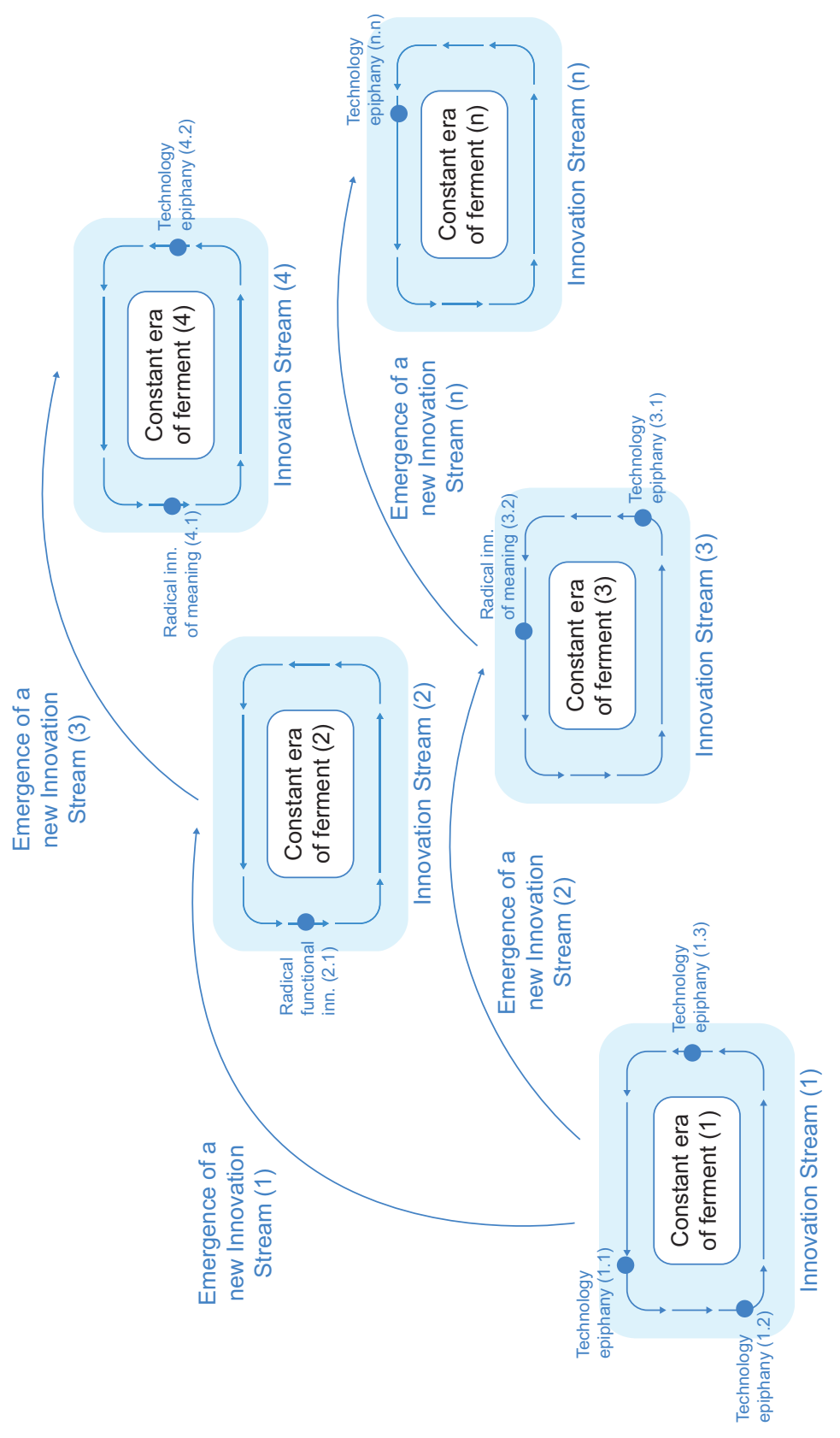

Figure 6.

A conceptual model for innovation dynamics 
This observation may both mean that the dominant design has not been reached yet, leaving each stream in a constant era of ferment, or that the dominant design does not exist as none of the designs has been able to establish itself in the market. Considering the analyses performed on the innovation matrices, it is possible to observe how 11 innovation streams out of 12 show the highest incidence of interventions in the incremental-incremental area of the matrix. This finding indicates how, for both functional and meaning dimensions, the market players leverage on meanings and functions that were previously introduced in the market by other players or by themselves. At the same time, these incremental reworks are often followed by other radical innovations, creating a fast and continuous interplay between radical and incremental interventions along both dimensions. These findings contribute to blurring the concept of "dominant design", challenging what had previously been found in other industries (Cappetta et al., 2006). There seem to be too many overlapping cycles to let a dominant design emerge, both at the industry level and at the single stream's level.

If traditional views on innovation dynamics describe how companies were used to fight against one another to establish their dominant design (e.g., Tripsas, 1997), companies can now focus on specific streams within the industry, possibly taking part in some of the innovation cycles.

These continuous reworks on both the technological and meaning dimensions are consistent with previous studies. They reflect how innovations previously introduced by competitors represent the basis for further innovations both in the technological domain (Tripsas, 1997) and in the meaning domain (Norman and Verganti, 2014). At the industry level, this rapid evolution and continuous improvement are extremely coherent with the shift from rigid to flexible product development models (Cooper and Sommer, 2016) and, more generally, to the agile methods and innovation approaches enabled by digital technologies (Downes and Nunes, 2014).

Figure 6 provides a conceptual model based on the findings of this study, taking inspiration from the original model of Tushman et al. (1997), while updating it by integrating the dynamics taking place on the functional dimension of innovation with a perspective on the meaning dimension. The model represents the industry, where multiple innovations streams (represented by the rectangles denominated "Innovation Stream") co-exist and evolve while, within each of the streams, an era of constant ferment takes place (as represented by the label) as multiple innovations unfold within the stream (represented the arrows and circles within each innovation stream). Different kinds of radical innovations take place in the different streams (represented by the circles and their denominations) relying on either innovation of meaning, function or both - i.e., technology epiphanies. These radical innovations are immersed in the constant era of ferment established within the innovation stream, where they are thus preceded and followed by several incremental innovations (represented by the continuous cycle of arrows). As the analysis is centered upon the innovation stream rather than the firms taking part to the industry, each cycle may involve multiple players from the industry as well as cover just one or both dimensions of innovation (meaning and/or functionalities). Nevertheless, as a new stream of innovation starts, with the introduction of a completely new functionality or meaning by one of the players, a new innovation stream emerges (as represented by the arrow "Emergence of a new Innovation Stream") without substituting the previous and extant ones but rather co-existing with them. Adopting this perspective, the original model (Tushman et al., 1997) can be updated to better capture the complexity of the scrutinized industry and the innovation dynamics relying on the two different dimensions of innovation (Verganti, 2009, 2011). Our model also illustrates the way multiple meanings can co-exist in the same industry (Trabucchi et al., 2017) and how the overall complexity and competition forces, leading to fast and continuous changes in the market (e.g., Downes and Nunes, 2014), hamper the emergence of a clear dominant design (Cappetta et al., 2006).
The evolution of meanings 
EJIM

25,6

116

Implications, limitations and future research

The present study sheds light on how innovation dynamics take place when also innovation in product and service meaning is involved. To do so, we gained insights from a field where both technological (e.g., Tushman et al., 1997) and meaning (e.g., Verganti, 2009) dimensions play a crucial role in determining the product's adoption and evolution: the social media industry.

From a theoretical perspective, this research offers a contribution to the strong and grounded literature on innovation dynamics in the technological domain (e.g., Abernathy and Utterback, 1978; Tushman et al., 1997), by integrating it with the growing literature on the innovation of meaning (e.g., Verganti, 2011). In particular, following insights from previous researches (e.g., Cappetta et al., 2006; Trabucchi et al., 2017), this article provides an updated model. It shows how different innovation approaches can co-exist in the same field, where different companies work in multiple innovation directions. Then, it shows how the speed, complexity and overlap of the industry dynamics make the emergence of a clear dominant design almost impossible, driven by the fast and continuous emergence of new cycles triggered by radical innovations. Hence, we propose that dominant designs and innovation cycles take place in "innovation streams", i.e., subsystems of innovation that concern comparable features of a given product or service, rather than at the product level. Within these streams, the introduction of different innovation approaches - i.e., technology-oriented, design-oriented or balanced between the two - causes the following incremental adaptation of different players in the market, until a company starts a new cycle.

As a conclusion, we propose a reflection on the generalizability of the results presented. The social media industry served the aim of this research by providing a paradigmatic empirical setting where the underlying service meaning has significantly evolved within a limited timeframe. Our results suggest that dominant designs do not emerge in such setting, due to the fast cycles of innovation characterizing the industry. Notwithstanding this, it is important to define the boundaries of contribution for these findings. As suggested by the literature on emerging technologies (Rotolo et al., 2015), the nature of digital technologies, and in particular their pace of growth, may be held accountable for failure of the emergence of a dominant design. Still, this finding is in contrast with the original model on technological innovation (Tushman et al., 1997) due to the high number of innovations introduced within a very limited timeframe. Nevertheless, the occurrence of this phenomenon - such as the impossibility to converge to a dominant design due to the co-existence and fast evolution of multiple, interconnected innovation streams - may provide valuable insights also beyond the social media industry. Indeed, our findings may be extended to all industries characterized by emerging technologies (Magistretti and Dell'Era, 2019; Rotolo et al., 2015), sharing the same crucial features of this empirical setting. Furthermore, as previously mentioned, social media services act as platforms where providers can simultaneously deliver multiple services to several sets of customers while leveraging the same digital platform, leading to the creation of multi-sided platforms (Gawer and Cusumano, 2014). Multi-sided platforms may act as a catalyst for embedding multiple and co-existing meanings within a service (Dell'Era et al., 2020).

More broadly, these considerations can serve as valuable for service industries that aim to propose multiple levels of experience (Artusi et al., 2020) especially those that include a digital component in the service experience. In other words, the implications of this research may serve industries that are well beyond the social media industry, especially for platform-based industries, and industries characterized by emerging technology, that may undergo similar innovation dynamics, involving the rapid emergence and evolution of multiple co-existing meanings and innovation streams.

From a managerial perspective, this research can aid innovators connect two fundamental innovation approaches: technology push and design-driven. Indeed, managers should be aware of the chance to rely on both dimensions when attempting to generate an industry shift, being 
conscious of its fast and relentless evolution. At the same time, this paper offers significant implications regarding strategic decisions on innovation. Given the lack of evidence on the emergence of dominant designs, managers may decide to focus on specific innovation streams and eventually sub-cycles within the stream. They know that they can leverage more than one stream at a time while not risking the chance to miss catching the wave of a new dominant design. Building on the previous reflections, managers in platform-based environments may benefit from the results of this research considering the co-existence of multiple meaning a relevant dimension to foster innovation, adding new sides, new value-added services and eventually embedding functions and meanings presented by other platforms in related value chains.

This research is not free from limitations. This represents a first attempt to update a consolidated model taking into consideration the complex and fast-changing environment of digital industries and two main dimensions of innovation. Therefore, the generalizability of the model is low, and future studies should dig into other empirical fields to test the discussed findings of this paper. Furthermore, no measures for performance are considered in this research, making it impossible to clarify whether the different approaches have different impacts on the cycles. As a consequence, future researches may consider this aspect, along with the relative relevance of the different innovation streams within an industry. In the end, although this research only analyzes eight companies, its focus is on the entire industry, rather than every single player's behavior. Another possible dimension of analysis for future research may consider the specific behavior of the different players involved.

\section{ORCID iDs}

Silvia Sanasi (Dhttp://orcid.org/0000-0002-5989-4032

Daniel Trabucchi ${ }^{D h t t p}: / / o r c i d . o r g / 0000-0003-1290-8043$

Elena Pellizzoni $\mathbb{D}_{\mathrm{http}} / /$ orcid.org/0000-0002-5016-4084

Tommaso Buganza (D)http://orcid.org/0000-0002-8170-9016

\section{References}

Abernathy, W.J. and Utterback, J.M. (1978), "Patterns of industrial innovation", Technology Review, Vol. 80 No. 7, pp. 40-47.

Abrahamson, E. and Rosenkopf, L. (1997), "Social network effects on the extent of innovation diffusion: a computer simulation", Organization Science, Vol. 8, pp. 289-309.

Altuna, N., Dell'Era, C., Landoni, P. and Verganti, R. (2017), "Developing radically new meanings through the collaboration with radical circles", European Journal of Innovation Management, Vol. 20 No. 2, pp. 269-290.

Anderson, P. and Tushman, M.L. (1990), "Technological discontinuities and dominant designs: a cyclical model of technological change", Administrative Science Quarterly, Vol. 35, pp. 604-633.

Armstrong, D., Gosling, A., Weinman, J. and Marteau, T. (1997), "The place of inter-rater reliability in qualitative research: an empirical study", Sociology, Vol. 31 No. 3, pp. 597-606.

Artusi, F. and Bellini, E. (2020a), "Design and the customer experience: the challenge of embodying new meaning in a new service", Creativity and Innovation Management, Vol. 29, pp. 152-161.

Artusi, F. and Bellini, E. (2020b), "The interplay between product and retail service meaning", International Journal of Retail and Distribution Management, In press.

Artusi, F., Bellini, E., Dell'Era, C. and Verganti, R. (2020), "Designing an omni-experience to save retailing: lessons from an Italian book retailer", Research-Technology Management, Vol. 63 No. 3, pp. 24-32.

Autio, E., Nambisan, S., Thomas, L.D. and Wright, M. (2018), "Digital affordances, spatial affordances, and the genesis of entrepreneurial ecosystems", Strategic Entrepreneurship Journal, Vol. 12 No. 1, pp. $72-95$.

The evolution of meanings 
EJIM

25,6

118

Belk, R.W. (1988), "Possessions and the extended self", Journal of Consumer Research, Vol. 15, pp. 139-168.

Bellis, P. and Verganti, R. (2020), "Pairs as pivots of innovation: how collaborative sensemaking benefits from innovating in twos", Innovation: Organization and Management, pp. 1-25, In press.

Candi, M., Ende, J. and Gemser, G. (2016), "Benefits of customer codevelopment of new products: the moderating effects of utilitarian and hedonic radicalness", Journal of Product Innovation Management, Vol. 33, pp. 418-434.

Cappetta, R., Cillo, P. and Ponti, A. (2006), "Convergent designs in fine fashion: an evolutionary model for stylistic innovation”, Research Policy, Vol. 35, pp. 1273-1290.

Christensen, C.M. and Bower, J.L. (1996), "Customer power, strategic investment, and the failure of leading firms", Strategic Management Journal, Vol. 18, pp. 197-218.

Christensen, C.M., McDonald, R., Altman, E.J. and Palmer, J.E. (2018), "Disruptive innovation: an intellectual history and directions for future research", Journal of Management Studies, Vol. 55 No. 7, pp. 1043-1078.

Christensen, C.M. (1997), The Innovator's Dilemma, Harvard Business School Press, Boston, MA.

Clement, J. (2017), Most Popular Social Networks Worldwide 2017, Statista, available at: https://www. statista.com/statistics/274773/global-penetration-of-selected-social-media-sites/.

Clement, J. (2020), Number of Global Social Network Users 2017-2025, Statista, available at: https:// www.statista.com/statistics/278414/number-of-worldwide-social-network-users/.

Cooper, R.G. and Sommer, A.F. (2016), "The agile-stage-gate hybrid model: a promising new approach and a new research opportunity", Journal of Product Innovation Management, Vol. 33, pp. 513-526.

Dell'Era, C. and Verganti, R. (2007), "Strategies of innovation and imitation of product languages", Journal of Product Innovation Management, Vol. 24, pp. 580-599.

Dell'Era, C. and Verganti, R. (2010), "Collaborative strategies in design-intensive industries: knowledge diversity and innovation", Long Range Planning, Vol. 43, pp. 123-141.

Dell'Era, C. and Verganti, R. (2011), "Diffusion processes of product meanings in design-intensive industries: determinants and dynamics", Journal of Product Innovation Management, Vol. 28, pp. 881-895.

Dell'Era, C., Marchesi, A., Verganti, R. and Zurlo, F. (2008), "Language mining: analysis of the innovation of dominant product languages in design-intensive industries", European Journal of Innovation Management, Vol. 11, pp. 25-50.

Dell'Era, C., Altuna, N., Magistretti, S. and Verganti, R. (2017), "Discovering quiescent meanings in technologies: exploring the design management practices that support the development of Technology Epiphanies", Technology Analysis and Strategic Management, Vol. 29, pp. 149-166.

Dell'Era, C., Trabucchi, D. and Magistretti, S. (2020), "Exploiting incumbents' potentialities: from linear value chains to multisided platforms", Creativity and Innovation Management, In press.

Di Stefano, G., Gambardella, A. and Verona, G. (2012), "Technology push and demand pull perspectives in innovation studies: current findings and future research directions", Research Policy, Vol. 41 No. 8, pp. 1283-1295.

Dosi, G. (1982), "Technological paradigms and technological trajectories: a suggested interpretation of the determinants and directions of technical change", Research Policy, Vol. 11 No. 3, pp. 147-162.

Downes, L. and Nunes, P. (2014), Big Bang Disruption: Strategy in the Age of Devastating Innovation, Penguin-Portfolio, New York.

Gawer, A. and Cusumano, M.A. (2014), "Industry platforms and ecosystem innovation", Journal of Product Innovation Management, Vol. 31, pp. 417-433.

Ghezzi, A. (2013), "Revisiting business strategy under discontinuity", Management Decision, Vol. 51, pp. 1326-1358. 
Ghezzi, A., Cortimiglia, M.N. and Frank, A.G. (2015), "Strategy and business model design in dynamic telecommunications industries: a study on Italian mobile network operators", Technological Forecasting and Social Change, Vol. 90, pp. 346-354.

Goto, S. (2017), "Technology epiphany and an integrated product and service”, Journal of Technology Management and Innovation, Vol. 12, pp. 34-44.

Grodal, S., Gotsopoulos, A. and Suarez, F.F. (2015), "The coevolution of technologies and categories during industry emergence", Academy of Management Review, Vol. 40 No. 3, pp. 423-445.

Holt, D. and Cameron, D. (2010), Cultural Strategy: Using Innovative Ideologies to Build Breakthrough Brands, Oxford University Press, Oxford.

Holt, D.B. (1997), "Poststructuralist lifestyle analysis: conceptualizing the social patterning of consumption in postmodernity", Journal of Consumer Research, Vol. 23, pp. 326-350.

Hopp, C., Antons, D., Kaminski, J. and Oliver Salge, T. (2018), "Disruptive innovation: conceptual foundations, empirical evidence, and research opportunities in the digital age", Journal of Product Innovation Management, Vol. 35 No. 3, pp. 446-457.

Howells, J. (1997), "Rethinking the market-technology relationship for innovation", Research Policy, Vol. 25, pp. 1209-1219.

Jepsen, L.B., Dell'Era, C. and Verganti, R. (2014), “The contributions of interpreters to the development of radical innovations of meanings: the role of 'Pioneering Projects' in the sustainable buildings industry”, R\&D Management, Vol. 44, pp. 1-17.

Kumar, M. and Noble, C.H. (2016), "Beyond form and function: why do consumers value product design?”, Journal of Business Research, Vol. 69 No. 2, pp. 613-620.

Lee, E., Lee, J. and Lee, J. (2006), "Reconsideration of the winner-take-all hypothesis: complex networks and local bias", Management Science, Vol. 52, pp. 1838-1848.

Lorenz, C. (1994), "Harnessing design as a strategic resource", Long Range Planning, Vol. 27, pp. 73-84.

Magistretti, S. and Dell'Era, C. (2019), "Unveiling opportunities afforded by emerging technologies: evidences from the drone industry", Technology Analysis and Strategic Management, Vol. 31 No. 5 , pp. 606-623.

Magistretti, S., Dell'Era, C., De Massis, A. and Frattini, F. (2019), "Exploring the relationship between types of family involvement and collaborative innovation in design-intensive firms: insights from two leading players in the furniture industry", Industry and Innovation, Vol. 26 No. 10, pp. 1121-1151.

Magistretti, S., Dell'Era, C. and Verganti, R. (2020), "Look for new opportunities in existing technologies: leveraging temporal and spatial dimensions to power discovery", ResearchTechnology Management, Vol. 63 No. 1, pp. 39-48.

McGrath, R.N. (1998), "Technological discontinuities and media patterns: assessing electric vehicle batteries", Technovation, Vol. 18 No. 11, pp. 677-687.

Morillo, M., Dell'Era, C. and Verganti, R. (2015), "Exploring the role of 'outsider' interpreters in the development of design-driven innovations", International Journal of Technology Intelligence and Planning, Vol. 10, pp. 222-253.

Nokelainen, T. and Dedehayir, O. (2015), "Technological adoption and use after mass-market displacement: the case of the LP record", Technovation, Vol. 36, pp. 65-76.

Norman, D.A. and Verganti, R. (2014), "Incremental and radical innovation: design research vs technology and meaning change", Design Issues, Vol. 30 No. 1, pp. 78-96.

Oliveira, P. and von Hippel, E. (2011), "Users as service innovators: the case of banking services", Research Policy, Vol. 40 No. 6, pp. 806-818.

Parry, M.E. and Kawakami, T. (2017), "The encroachment speed of potentially disruptive innovations with indirect network externalities: the case of E-readers", Journal of Product Innovation Management, Vol. 34 No. 2, pp. 141-158. 
EJIM 25,6

Perez, C. (2010), "Technological revolutions and techno-economic paradigms", Cambridge Journal of Economics, Vol. 34 No. 1, pp. 185-202.

Pinto, G.L., Dell'Era, C., Verganti, R. and Bellini, E. (2017), "Innovation strategies in retail services: solutions, experiences and meanings", European Journal of Innovation Management, Vol. 20 No. 2, pp. 190-209.

Ramaswamy, V. and Ozcan, K. (2018), "What is co-creation? An interactional creation framework and its implications for value creation”, Journal of Business Research, Vol. 84, pp. 196-205.

Ravasi, D. and Lojacono, G. (2005), "Managing design and designers for strategic renewal", Long Range Planning, Vol. 38, pp. 51-77.

Rotolo, D., Hicks, D. and Martin, B.R. (2015), "What is an emerging technology?", Research Policy, Vol. 44 No. 10, pp. 1827-1843.

Roy, R. and Sarkar, M.B. (2016), "Knowledge, firm boundaries, and innovation: mitigating the incumbent's curse during radical technological change", Strategic Management Journal, Vol. 37 No. 5, pp. 835-854.

Sawhney, M., Verona, G. and Prandelli, E. (2005), "Collaborating to create: the Internet as a platform for customer engagement in product innovation”, Journal of Interactive Marketing, Vol. 19 No. 4, pp. 4-17.

Schilling, M.A. (2002), "Technology success and failure in winner-take-all markets: the impact of learning orientation, timing, and network externalities", Academy of Management Journal, Vol. 45, pp. 387-398.

Sood, A. and Tellis, G.J. (2005), "Technological evolution and radical innovation", Journal of Marketing, Vol. 69 No. 3, pp. 152-168.

Sood, A. and Tellis, G.J. (2011), "Demystifying disruption: a new model for understanding and predicting disruptive technologies", Marketing Science, Vol. 30 No. 2, pp. 339-354.

Tegarden, L.F., Hatfield, D.E. and Echols, A.E. (1999), "Doomed from the start: what is the value of selecting a future dominant design?”, Strategic Management Journal, Vol. 20 No. 6, pp. 495-518.

Trabucchi, D., Pellizzoni, E., Buganza, T. and Verganti, R. (2017), "Interplay between technology and meaning: how music majors reacted?", Creativity and Innovation Management, Vol. 26 No. 4, pp. 327-338.

Trabucchi, D., Talenti, L. and Buganza, T. (2019), "How do Big Bang Disruptors look like? A business model perspective”, Technological Forecasting and Social Change, Vol. 141, pp. 330-340.

Tripsas, M. (1997), "Unraveling the process of creative destruction: complementary assets and incumbent survival in the typesetter industry", Strategic Management Journal, Vol. 18, pp. 119-142.

Tushman, M.L. and Anderson, P. (1986), "Technological discontinuities and organizational environments", Administrative Science Quarterly, Vol. 35, pp. 439-465.

Tushman, M.L., Anderson, P.C. and O'Reilly, C. (1997), “Technology cycles, innovation streams, and ambidextrous organizations: organization renewal through innovation streams and strategic change", Managing strategic innovation and change, Vol. 34, pp. 3-23.

Utterback, J.M. and Suárez, F.F. (1993), "Innovation, competition, and industry structure”, Research Policy, Vol. 22, pp. 1-21.

Verganti, R. (2009), Design-driven Innovation: Changing the Rules of Competition by Radically Innovating what Things Mean, Harvard Business Press, Boston.

Verganti, R. (2011), "Radical design and technology epiphanies: a new focus for research on design management", Journal of Product Innovation Management, Vol. 28, pp. 384-388.

Verganti, R. (2017), Overcrowded: Designing Meaningful Products in a World Awash with Ideas, MIT Press, Cambridge.

Verganti, R. and Öberg, А. (2013), "Interpreting and envisioning — a hermeneutic framework to look at radical innovation of meanings", Industrial Marketing Management, Vol. 42, pp. 86-95. 
Verganti, R., Vendraminelli, L. and Iansiti, M. (2020), "Innovation and design in the age of artificial intelligence", Journal of Product Innovation Management, Vol. 37 No. 3, pp. 212-227.

Von Hippel, E. (1976), "The dominant role of users in the scientific instrument innovation process", Research Policy, Vol. 5 No. 3, pp. 212-239.

Von Hippel, E. (1986), "Lead users: a source of novel product concepts", Management Science, Vol. 32, pp. 791-805.
The evolution of meanings

Annex

The Annex is available online for this article

\section{About the authors}

Silvia Sanasi is a $\mathrm{PhD}$ candidate in strategic management, innovation and entrepreneurship at the School of Management of Politecnico di Milano, where she also collaborates as a researcher in the hi-tech startups and startup intelligence observatories. Her research interests encompass experimentation in business model design, innovation and scaling, with focus on scientific approaches such as the lean startup approach (LSA) as well as the strategic implications of innovation management and digital platforms. She is author of several refereed journal articles (appearing in outlets such as Research-Technology Management, Technology Analysis and Strategic Management, Journal of Small Business and Enterprise Development, Competitiveness Review) and conference proceedings. Silvia Sanasi is the corresponding author and can be contacted at: silvia.sanasi@polimi.it

Daniel Trabucchi is a post-doc researcher at the School of Management of Politecnico di Milano, where he serves as a researcher of LEADIN'Lab, the Laboratory for Leadership, Design and Innovation. His research interests are focused in innovation management. In particular, he has been working on digital two-sided platforms and their peculiarities (focusing on how they can create and capture value and the related data-driven business models); moreover he focuses on innovation strategy based on the interplay between technology and meaning. His research has been published in peer-reviewed journals such as Technological Forecasting and Social Change, Internet Research, Research-Technology Management, Creativity and Innovation Management, Technology Analysis and Strategic Management and European Journal of Innovation Management; he is also a reviewer for many of these journals.

Elena Pellizzoni is an assistant professor at the School of Management of Politecnico di Milano where she serves as a researcher of LEADIN'Lab, the Laboratory for Leadership, Design and Innovation. Her research interests are focused in innovation Management. In particular, she has been working on selfengagement innovation activities such as innovation contests, calls for ideas and idea management systems. She is also focused on mechanisms of value creation and appropriation in mobile apps and the role of the interplay between technology and meaning in high-tech industries.

Tommaso Buganza is an associate professor of leadership and innovation at the School of Management of Politecnico di Milano where he also is co-founder of LEADIN'Lab, the Laboratory for Leadership, Design and Innovation. He is a lecturer in innovation management and project management, responsible for the project management academy and coordinator of the innovation and training area at MIP (Politecnico di Milano Graduate School of Business). He is a member of the scientific committee of the International Product Development Management Conference EIASM-IPDMC. His research activity explores the intersection between technological innovation and leadership and has been published in peer-reviewed journals such as Journal of Product Innovation Management, International Journal of Project Management, International Journal of Innovation Management, European Journal of Innovation Management and Creativity and Innovation Management and in a number of books; he is also a reviewer for many of these journals.

For instructions on how to order reprints of this article, please visit our website:

www.emeraldgrouppublishing.com/licensing/reprints.htm

Or contact us for further details: permissions@emeraldinsight.com 